\title{
Coaching and coaches in the COVID-19 situation. The Polish perspective
}

\author{
Piotr Unierzyski $i^{a} \&$ Tomasz Iwanski ${ }^{a}$ \\ ${ }^{a}$ Polish Tennis Association, Warsaw, Poland.
}

ABSTRACT

The purpose of this article is to share the situation faced by Polish tennis in relation to the COVID-19 pandemic. The beginning of the 2020 looked just like the next prosperous year to come. With a new and dynamic leadership, the Polish Tennis Association (PTA) have been looking forward into the future. The budget was growing and all programmes and activities, from performance sport to Tenis 10 were also growing. The different projects are presented and discussed.
Key words: COVID-19, coaching, coaches.

Received: 18 May 2020

Accepted: 20 June 2020

Corresponding author: Piotr Unierzyski, Polish Tennis Association, Marszalkowska 00581, Warsaw, Poland. Email: piotrunierzysky@wp.pl

\section{INTRODUCTION}

The beginning of the 2020 looked just like the next prosperous year to come. With a new and dynamic leadership, the Polish Tennis Association (PTA) have been looking forward into the future. The budget was growing and all programmes and activities, from performance sport to Tenis 10 were growing, too. We were looking forward and preparing for our major event - a Davis Cup tie against Hong Kong, in conjunction with the annual XXXI Tennis Coaches Conference in Kalisz, the oldest city in Poland.

The COVID-19 situation already "existed" but abroad. The first case became known on $4^{\text {th }}$ March when players from Hong Kong were already in the country for the Davis Cup tie (Corona Tracker, 2020). Due to the changing nature of the situation, the local authorities decided not to cancel the Davis Cup tie but to play it without audience (Tennis World, 2020). So, the coaches conference was at the same time and venue but the attendants could not watch matches. Because of this decision, it was agreed to extend the programme of the conference up to 3 days in order to provide a better use of the time for the approximately 250 coaches attending. In fact, were very lucky because just some days later all activities were suspended, including all our events like pre-season camps, coaches' courses and tennis 10 tournaments.

The necessary isolation changed coaches and players life from one day to another and in many cases, became quite dramatic. As it is the case in many other countries, the vast majority of tennis coaches in Poland are self-employed (Gowling, 2019). Therefore, their income is mostly based of on-court activities. They obviously could not work on line. Thanks to the quick decisions of the national government, that announced an anticrisis programme called the "Financial Shield", which included assistance reliefs in the repayment of the loans and in the cancelling or deferring of rents, the situation of the selfemployed coaches was alleviated. On average, a tennis coach could get directly or indirectly approximately $\$ 3000$ of public assistance (British Polish Chamber of Commerce, 2020).

\section{ACTIVITIES}

The Polish Tennis Association tried to deal with the situation as a kind of blessing and opportunity - suddenly we have got an extra time for us. PTA and ATT (Academy of Tennis Coaches) immediately announced an initiative - "If we can't play - let's study". We have welcomed with thankfulness the ITF's initiative to use ITF Academy for free, and at the moment there are almost 550 Polish coaches registered (ITF Academy, 2020). In addition, the national educational platform has been created with 300 coaches participating in the PTF certification courses. This was a relatively easy process as the PTF has been already working on adding e-learning activities into the regular courses for over 2 years, so the situation only speeded up the implementation process (Mester \& Wigger, 2001; Over \& Sharp, 2008).

The e-learning content of the PTF coach education programme is quite straight forward since in order for the coaches to finalise the courses (PT CBI, CAP or HP), they have to complete the on-line section of each course by reading the content and answering to several questions. The questions (and answers) change in order to keep the coaches informed and entertained at the same time. The completion of a module 
was a condition to be accepted to take part in a face-to-face course in June (Sackey-Addo \& Pérez, 2016).

We must admit that that we regret that we did not start the elearning as a part of traditional courses earlier. From our perspective - when it was again allowed to restart the courses, the candidates who followed the ITF Academy presentations and passed the on-line tests, on both platforms were much better prepared for the practical parts of the courses and, therefore this made it easier for the tutors or facilitators to transform knowledge into competences. We truly believe this is a fundamental tool for the coaches (Cushion et al., 2010).

The conclusion of this section is that it was really worth to use the lockdown as an opportunity for further development of our coaching system and we believe that we will be ready to apply for an ITF Recognition of our Coach Education System at gold level very soon.

\section{RETURN TO PLAY}

The other area in which we were quite efficient was that of the return to play and, slightly later to competitions in all age groups. Our President Miroslaw Skrzypczynski, the board and the Head Coach Tomasz Iwanski did a big effort to persuade the Ministry of Sports that tennis is a very safe sport. Due to their in-depth knowledge of the game, they put together new safety rules for tennis which were presented to the Ministry of Sports and permission was asked to return to play as the very first sport. The rules and procedures were quite strict but necessary to a safe return to play under the new conditions. All tennis clubs (except the indoor facilities) returned to play during May. Besides, the PTF have also organised training camps for all national teams from $12 \&$ under to Fed Cup and Davis Cup.

The next step was to return to competitions. All age groups including the Wheelchair Tour started their competitions. The original plan of organising a series of ITF events was turned into the idea of organising a series of tournaments called "LOTOS PZT Polish Tour" with a prize money of over $\$ 400$.

As per the main events, the national championships have started from the beginning of July. The National Women and Men Championships will offer 40,000\$ in prize money. Top players including Kamil Majchrzak and Hubert Hurkacz will take part in this event.

\section{PROGRAMME OF TALENT IDENTIFICATION}

The last project which we are proud of, planned as a new initiative for 2020, is the Programme of Talent Identification (PIT). The original plan of this programme was to monitor a number of players aged 9-11 years old during the spring time. Then, the most promising ones would be identified and invited to take part in talent identification camps that will be organised during the summer (Unierzyski, 2002; 2003; 2006; Unierzyski, Wielinski, \& Zhanel, 2003). Due to the fact that the competitions were cancelled, we have asked all licenced coaches to directly nominate their most talented players to the programme. Furthermore, we have established simple selection procedures and have asked the coaches to send us video clips that included one motor test (agility run) and several strokes including the serve. Over 200 coaches sent video clips of their players. Obviously, the information that the talent identification team got was somehow limited but good enough to invite almost 100 players for "Orange", "Green" and "Yellow" 10-day camps that will be staged in August.

\section{CONCLUSION}

The purpose of this article has been to provide a general overview of the programmes organised by the Polish Tennis Association in order to continue with the activity during the COVID-19 pandemic.

A number of different projects have been presented with the intention to describe the challenges and solutions that PTA, coaches, players and different tennis stakeholders in our country have faced during these times.

As specifically relates to coach education, it is well known that one of the coaches' competences is the ability to adapt to various situations. We believe that our association, board and the coaches did a good job during these difficult times, and effectively assisted our players to continue their development.

\section{REFERENCES}

British Polish Chamber of Commerce. (2020). The Corona Shield - Poland's response, available at: http://bpcc.org.pl/en/news/the-corona-shield-poland'sresponse

Corona Tracker. (2020). Poland. Available at: https://www.coronatracker.com/country/poland/

Cushion, C., Nelson, L., Armour, K., Lyle, J., Jones, R., Sandford, R., \& O'Callaghan, C. (2010). Coach learning and development: A review of literature. Leeds: Sports Coach UK.

Gowling, C. (2019). Examining tennis coaches constructions of their role in a performance setting: What is it like to coach an elite junior tennis player? (Doctoral dissertation, Liverpool John Moores University).

ITF Academy. (2020). www.itf-academy.com

Mester, J. \& Wigger, U. (2011). Online resources for coaches education: Motivation for applied Intellectual Capital Management in tennis, ITF Coaching and Sport Science Review, 54, 19-20.

Over, S. \& Sharp, B. (2008). Information Technology in tennis, ITF Coaching and Sport Science Review, 15 (45): 24-25.

Sackey-Addo, R., \& Pérez, J. (2016). The evolution of online education for sports coaches: A tennis perspective. ITF Coaching \& Sport Science Review, 68, 24, 8-9.

Tennis World (2020). Poland and Hong Kong to play without spectators due to Coronavirus concerns. Available at: https://www.tennisworldusa.org/tennis/news/Davis_Cup /84858/poland-and-hong-kong-to-play-withoutspectators-due-to-coronavirus-concerns- $/$

Unierzyski, P. (2006). Foundations for talent identification and player development programmes. Editorial C.

Unierzyski, P. (2003). Level of achievement motivation of 
young tennis players and their future progress. Journal of Sports Science \& Medicine, 2(4), 184.

Unierzyski, P. (2002). In search of data for a long-term planning and periodisation in tennis: development vs. results. In Proceedings of the 7th International sport sciences congress (pp. 146-155).

Unierzyski, P., Wielinski, D., \& Zhanel, J. (2003). Searching for reasons for success and failure in the careers of young tennis players-a study of two individual cases. In Proceedings of the ITF worldwide coaches symposium ( $p$. 138). Vilamoura, Portugal: ITF.

RECOMMENDED ITF TENNIS ACADEMY CONTENT (CLICK BELOW)

\section{ITF Academy}

Copyright (c) 2020 Piotr Unierzyski \& Tomasz Iwanski

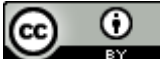

This text is under a Creative Commons BY 4.0 license

You are free to Share - copy and redistribute the material in any medium or format - and Adapt the content - remix, transform, and build upon the material for any purpose, even commercially under the following terms:

Attribution: You must give appropriate credit, provide a link to the license, and indicate if changes were made. You may do so in any reasonable manner, but not in any way that suggests the licensor endorses you or your use.

CCBY4.0 license terms summary CCBY4.0license terms 